\title{
Telenursing and self-management among patient with hypertension
}

\author{
Sri Sakinah*, Sulkifli Nurdin \\ STIKES Muhammadiyah Sidrap. *Corresponding author. Email: ns.srisakinah@gmail.com
}

\begin{abstract}
Background: Hypertension is still a risk factor for the leading cause of death in the world. Hypertension is a blood pressure condition of more than $140 / 90 \mathrm{mmHg}$. Patient with hypertension who are an uncontrolled their blood pressure and the number continues to increase, one of which is through services nursing. Nurses are one of the health professions involved in achieving health development goals both in the world and in Indonesia. Health information technology is increasingly developing which must be of concern, especially in the world of nursing to help answer health problems public through telenursing which was developed by providing telecommunications assistance via WhatsApp.

Purpose: To determine the effect of telenursing and self-management among patient with hypertension

Methods: This study was conducted in June - August 2020 with a method quasi experimental pre and post test with control group (giving treatment telenursing via WhatsApp to the intervention group and control group using the media short message service (SMS). The sample in this study were all patients with hypertension in accordance with the inclusion criteria (hypertensive patients who undergo treatment, have android, and are able to read and write) The media used in this study were cell phones

Results: Through the Paired Sample Test it is known that the $p$ value in thegroup is controlled SMS based on systolic blood pressure was $0.008(<0.05)$, while in the intervention group the WA p value was $0.001(<0.05)$. This shows a significant result, but the researchers considered that the intervention group had a more significant value when compared to the control. Likewise, the diastolic blood pressure in which the control group was obtained $p$ value $0.051(>0.05)$ while the intervention group obtained $p$ value of $0.000(<0.05)$.

Conclusion: There was no significant difference in blood pressure in the group, control use media short message service (SMS). While the intervention group showed a very significant difference between before and after telenursing used media WhatsApp
\end{abstract}

\section{Keywords: Telenursing; Self-management; Patient; Hypertension}

\section{BACKGROUND}

The disease pattern is currently undergoing an epidemiological transition from infectious diseases/ Communicable Diseases (CDs) to noncommunicable diseases (NCDs). NonCommunicable Diseases (NCDs) has become a public health problem globally, nationally, regionally and even locally. Hypertension is one of the NCDs diseases that cause the most death. Hypertension is a condition when blood pressure in blood vessels increases chronically where the heart works harder to pump blood to meet the body's oxygen and nutritional needs (Warganegara, \& Nur, 2016; Trisnowati, 2018; Zanna, 2019; Nuraini, 2015).

Data from the World Health Organization (WHO) in 2015, states that hypertension contributes to nearly 9.4 million deaths each year due to cardiovascular disease. WHO says that $40 \%$ of developing economies have hypertension sufferers, while only around 35\% are developed countries. In Southeast Asia, there are 36\% of adults who suffer from hypertension and it has killed 1.5 million people every year. The number of hypertension sufferers each year will increase. In 2025 it is predicted that there will be an increase of around $29 \%$ or 1.6 billion adults worldwide (Ministry of Health of The Republic of Indonesia, 2019).

The prevalence of hypertension in South Sulawesi, which was obtained through measurements at the age of 35 years was $5.73 \%$, at the age of 45 was $12.62 \%$, at the age of 60 was $23.31 \%$ and at the age of 75 was $24.04 \%$. Patients with hypertension were diagnosed by health workers who were diagnosed by a doctor or were taking medication by $10.5 \%$ and in 2018 there were 21,142 cases of hypertension sufferers in South Sulawesi. (Ministry of Health of The Republic of Indonesia, 2018). 
Telenursing and self-management among patient with hypertension

Data from the Sidenreng Rappang District Health Office in 2018, the number of hypertension sufferers was 9,377 people with a presentation of $33.8 \%$ and in 2019 January to July there were 2,301 people with a presentation of $12.4 \%$. Based on the initial survey data obtained from the Lawawoi Health Center from January to June there were 382 cases with hypertension. This will continue to increase if it is not controlled properly. Controlling or managing hypertension can be done as an effort to reduce the risk of rising blood pressure and its treatment (Nurhidayati, et al., 2019).

Based on the survey conducted by researchers, the results of interviews were obtained related to the program conducted by the Puskesmas in order to reduce the incidence of hypertension in the working area of the Lawawoi Health Center, namely the prolanis program. Puskesmas also serves patients every hour in order to control blood pressure. However, there are several obstacles in this, one of which is the distance of the patient's house which is too far away so that sometimes patients are too lazy to visit a health service center.

Based on the results of research conducted by Fadhila, \& Afriani, (2020), nurses are increasingly required to be more professional and follow technological developments, including being able to take advantage of information technology in the field of nursing services, where patients who need nursing care can come from various circles in the world. virtual services that can be accessed through remote nursing services between patients and nurses wherever they are. One of the nursing care services via cell phone is telenursing. Telenursing is the use of technology to provide nursing care services and remote nursing practice to patients with the aim of improving health care (Asiri, \& Househ, 2016; Sharma, 2014; Ajalli, \& Fallahi, 2015; Ahiave, \& Tom Luma, 2013). One of the services provided is in the form of hypertension management including control, medication, and lifestyle.

In the management of hypertension, nurses have a role in changing the behavior of sufferers in order to avoid a disease or reduce the risk of illness. Nurses have a role as educators about hypertension information in increasing patient knowledge and can form a positive attitude so that they can treat hypertension independently so that complications can be prevented through telenursing assistance. Telenursing is the use of information communication technology to provide nursing care (Damayantie, et al., 2018; Sunarti, \& Patimah, 2019; Silalahi, 2020; Souza, et all., 2016). Telenursing is a technology nursing service where there is a long distance between nurse and patient which aims to monitor the patient's condition including blood pressure (Padila, et al., 2018; Pangan, 2011).

\section{RESEARCH METHODS}

A quantitative research with a method quasiexperimental pre test and post test (providing telenursing treatment via WhatsApp/intervention group and providing telenursing treatment via media short message service (SMS) /control group. The sample in this study were all hypertensive patients divided into two groups. groups, each of which consists of 10 participants in the group WhatsApp and 10 participants in the short message service (SMS) group and according to the inclusion criteria (hypertensive patients who are undergoing treatment, have androids, and are able to read and write) and the media used is telephone As for the research activities for one month by keep always remind the participants every day through WhatsApp (WhatsApp Group) and media short message service (SMS)(for each participant). The messages sent include matters in handling hypertension such as: routine carry out blood pressure control; routinely taking a anti hypertension drugs as doctor's order; consuming traditional/complementer ingredients such as celery leaf stew by taking 15 celery stalks whole and washed clean then chopped and boiled in 3 cups of water until boiling and the remaining half and consumed twice a day after meals; Maintain ideal body weight (not fat); Reducing the use of salt; Light exercise; Do not smoke. Blood pressure measurements were carried out twice at the start of the study and at the end of the study for one month to evaluate the participants' blood pressure. 
Telenursing and self-management among patient with hypertension

\section{RESULTS}

Table 1. Demographic Characteristics of Respondents $\mathrm{N}=\mathbf{2 0}$

\begin{tabular}{|c|c|c|c|c|}
\hline Demographic & & $\mathrm{n}$ & $\%$ & $M \pm S D$ \\
\hline Control Group Age (Years) (Range: 58-85) & & 10 & & $69.3 \pm 9.74$ \\
\hline Intervention Group Age (Years) (Range: 45-66) & & 10 & & $57.3 \pm 6.03$ \\
\hline Duration of illness (Years) (Range: 10-27) & & 20 & & $17.15 \pm 5.214$ \\
\hline Gender (SMS Telenursing Group) & $\begin{array}{l}\text { Male } \\
\text { Female }\end{array}$ & $\begin{array}{l}2 \\
8\end{array}$ & $\begin{array}{l}20.0 \\
80.0\end{array}$ & \\
\hline Gender (WA Telenursing Group) & $\begin{array}{l}\text { Male } \\
\text { Female }\end{array}$ & $\begin{array}{l}2 \\
8\end{array}$ & $\begin{array}{l}20.0 \\
80.0\end{array}$ & \\
\hline Occupation & $\begin{array}{l}\text { Unemployers } \\
\text { Housewife } \\
\text { Private employees } \\
\text { Entrepreneur }\end{array}$ & $\begin{array}{c}2 \\
10 \\
2 \\
6\end{array}$ & $\begin{array}{l}10.0 \\
50.0 \\
10.0 \\
30.0\end{array}$ & \\
\hline
\end{tabular}

Based on table 1. it is known that the control group respondents were 10 people aged between 58 years to 85 years with a mean of 69.3 and a standard deviation of 9.74 . While the respondents in the intervention group were 10 people aged between 45 years to 66 years with a mean of 57.3 and a standard deviation of 6.03 . Judging from the length of illness, respondents ranged from 10 to 27 years with an average of 17.15 years. The majority of respondents' occupations are housewives (50.0\%).

Table 2. Results of Normality Test of Blood Pressure Values in the Control and Intervention Groups

\begin{tabular}{lcc}
\hline Group & $\boldsymbol{p}$ value & Result \\
\hline Pre Test SMS Control & 0,118 & Normal \\
Post Test SMS Control & 0,060 & Normal \\
Pre Test WA Intervention & 0,169 & Normal \\
Post Test WA Intervention & 0,072 & Normal \\
\hline
\end{tabular}


Table 3: Average Blood Pressure Value Before and After Telenursing

\begin{tabular}{llc}
\hline Blood Pressure & \multicolumn{1}{c}{ Mean } \\
\hline Before Intervention & Systolic & \\
& SMS Telenursing Group & $134 \mathrm{mmHg}$ \\
& WA Telenursing Group & $140 \mathrm{mmHg}$ \\
& Diastolic & \\
& SMS Telenursing Group & $84 \mathrm{mmHg}$ \\
& WA Telenursing Group & $82 \mathrm{mmHg}$ \\
& Systolic & \\
After Intervention & SMS Control Group & $124 \mathrm{mmHg}$ \\
& WA Intervention Group & $128 \mathrm{mmHg}$ \\
& Diastolic & \\
& SMS Control Group & $78 \mathrm{mmHg}$ \\
& WA Intervention Group & $74 \mathrm{mmHg}$ \\
\hline
\end{tabular}

\section{Before Intervention}

Based on table 3. it is known that the mean systolic blood pressure in the SMS intervention group before telenursing was $134 \mathrm{mmHg}$, while the WA group intervention group was $140 \mathrm{mmHg}$. Meanwhile, the mean diastolic blood pressure in the SMS intervention group before telenursing was $84 \mathrm{mmHg}$, while in the WA group it was $82 \mathrm{mmHg}$.

\section{After intervention}

Based on table 3. It is known that the mean systolic blood pressure after telenursing SMS group is $124 \mathrm{mmHg}$, whereas in the group Group WA is $128 \mathrm{mmHg}$. Meanwhile, the mean diastolic blood pressure in the SMS intervention group after telenursing was $78 \mathrm{mmHg}$, while in the WA group it was $74 \mathrm{mmHg}$.

Table 4. Comparison of Blood Pressure Before and After in the Intervention.

\begin{tabular}{lccc}
\hline Blood Pressure & N & Mean & p Value \\
\hline Systolic & & & \\
SMS Control Group & 10 & $10 \mathrm{mmHg}$ & 0,008 \\
WA Intervention Group & 10 & $12 \mathrm{mmHg}$ & 0,001 \\
& & & \\
Diastolic & & & \\
SMS Control Group & 10 & $6 \mathrm{mmHg}$ & 0,051 \\
WA Intervention Group & 10 & $8 \mathrm{mmHg}$ & 0,000 \\
\hline 0,05, paired t-test & & &
\end{tabular}

Based on table 4. it is known that the mean difference in systolic blood pressure in the SMS control group before and after telenursing was 10 $\mathrm{mmHg}$, while in the WA group intervention group was $12 \mathrm{mmHg}$. While average blood pressure difference diastolik in the control group before and after telenursing SMS was $6 \mathrm{mmHg}$, whereas the intervention group WA Group amounted to 8 $\mathrm{mmHg}$.

After analyzing using the Paired Sample Test, the $p$ value was more significant in the WA Group intervention group, namely 0.001 for systolic blood pressure and 0.000 for diastolic blood pressure, when compared to the SMS control group of 0.008 
Telenursing and self-management among patient with hypertension

at systolic blood pressure and 0.051 on diastolic blood pressure. So the researchers stated that telenursing using WA was more effective in the management of hypertensive patients.

\section{DISCUSSION}

Based on the results of the Paired Sample Test, it is known that the $p$ value in thegroup control SMS based on systolic blood pressure was $0.008(<0.05)$, while in the WA intervention group the $p$ value was $0.001 \quad(<0.05)$. This shows a significant result, but researchers consider that the intervention group has a more significant value when compared to the control group. Likewise with diastolic blood pressure where the control group obtained a $p$ value of $0.051(>0.05)$ while in the intervention group obtained $p$ value of 0.000 $(<0.05)$ was. This shows that there is no significant difference in diastolic blood pressure in thegroup control while in the intervention group shows a very significant difference between before and after telenursing.

According to researchers, with increasingly advanced technological developments, one can choose a treatment method, one of which is telenursing. Telenursing using SMS media is considered less effective when compared to WA media because according to researchers almost everyone is more interested in using internet media in interacting, especially the WhatsApp application because this application provides more features such as voice recordings, videos, images and so on compared to SMS media containing only text.

The results of this study are in line with the research by Pratama, et al., (2019) which states that there is a significant effect of telenursing on self-care for patients with chronic diseases. This can be seen from the results of his research which examined 60 respondents with the test results obtained by $p=0.000<0.05$. Telenursing is a new method of nursing care which includes the use of websites, social media, telephones, mobile phones in providing care to patients in a very effective and efficient manner, it can also reduce patient treatment costs and reduce the number of visits to the hospital for acute conditions between periods. chronic.

Telenursing can help reduce the days of care for patients with chronic illnesses in the hospital because patients can be chained back via long- distance telecommunications regarding conditions and complaints that occur when the patient is at home (Wootton, et al., 2015; Lindberg, et all., 2013; )

The same is found in the management of other chronic diseases as in diabetics. Research conducted by Pratama, et al., 2015) states that effectiveness goodis related to the application of telenursing in diabetic ulcer patients. In this study, it was found that there was a significant improvement in the ability of community nurses in diabetic ulcer care management between before and after the intervention through telenursing.

According to Fadhila, \& Afriani, (2020) there are things that can have a big positive impact so that it can make a patient with certain chronic diseases feel better after receiving intervention or remote care using communication media. These impacts include, among other things, a growing sense of trust and confidence in the patient regarding the treatment that medical personnel will provide for the disease they are experiencing.

\section{CONCLUSION}

There was no significant difference in diastolic blood pressure in thegroup control while the intervention group showed a very significant difference between before and after telenursing.

\section{SUGGESTION}

The results of this study are expected to be input for the Puskesmas to carry out assistance in the management of hypertension for patients who have long distances from home so that blood pressure is controlled through telenursing assistance.

\section{REFERENCES}

Ahiave, E., \& Tom Luma, J. (2013). Nursing interventions for improving the management of hypertension in adults.

Ajalli, A., \& Fallahi Khoshknab, M. (2015). Tele nursing care in chronic patients/a systematic review. Iranian Journal of Rehabilitation Research, 1(3), 76-86. 
Asiri, H., \& Househ, M. (2016). The Impact of Telenursing on Nursing Practice and Education: A Systematic Literature Review. Studies in health technology and informatics, 226, 105108.

Damayantie, N., Heryani, E., \& Muazir, M. (2018). Faktor-Faktor yang Mempengaruhi Perilaku Penatalaksanaan Hipertensi oleh Penderita di Wilayah Kerja Pskesmas Sekernan llir Kabupaten Muaro Jambi tahun 2018. Jurnal Ners dan Kebidanan (Journal of Ners and Midwifery), 5(3), 224-232.

Fadhila, R., \& Afriani, T. (2020). Penerapan Telenursing Dalam Pelayanan Kesehatan: Literature Review. Jurnal Keperawatan Abdurrab, 3(2), 77-84.

Lindberg, B., Nilsson, C., Zotterman, D., Söderberg, S., \& Skär, L. (2013). Using information and communication technology in home care for communication between patients, family members, and healthcare professionals: a systematic review. International journal of telemedicine and applications, 2013.

Ministry of Health of The Republic of Indonesia (2018). Hasil Utama Riskesdas 2018. Jakarta: Kementerian Kesehatan RI. Retrieved from: https://www.kemkes.go.id/resources/download/i nfo-terkini/hasil-riskesdas-2018.pdf

Ministry of Health of The Republic of Indonesia (2019). Hipertensi Penyakit Paling Banyak Diidap Masyarakat. Jakarta: Kementerian Kesehatan RI. Retrieved from: https://www.kemkes.go.id/article/view/1905170 0002/hipertensi-penyakit-paling-banyak-diidapmasyarakat.html

Nuraini, B. (2015). Risk factors of hypertension. Jurnal Majority, 4(5).
Nurhidayati, I., Aniswari, A. Y., Sulistyowati, A. D., \& Sutaryono, S. (2019). Penderita Hipertensi Dewasa Lebih Patuh daripada Lansia dalam Minum Obat Penurun Tekanan Darah. Jurnal Kesehatan Masyarakat Indonesia, 13(2), 1-5.

Padila, P., Lina, L. F., Febriawati, H., Agustina, B., \& Yanuarti, R. (2018). Home Visit Berbasis Sistem Informasi Manajemen Telenursing. Jurnal Keperawatan Silampari, 2(1), 217-235.

Pangan, I. K., Pangilinan, G. A., Pangilinan, M., Pangilinan, R., Pangilinan, R., Par, C. J., \& Paragas, E. (2011). Telenursing through SMS (short messaging service): it's effect on knowledge and adherence. International Journal of Public Health Research, (Special issue), $115-120$.

Pratama, I. W. W., Nurhesti, P. O. Y., \& Sulistiowati, M. D. (2019). Pengaruh Telenursing Terhadap Perawatan Diri Pasien Dengan Penyakit Kronis.

Sharma, S. B. (2014). Telenursing-A potential resource in the eHealth agenda of India. Journal of the International Society for Telemedicine and eHealth, 2, 19-28.

Sidenreng Rappang District Health Authority. (2019). Jumlah Penderita Hipertensi. Pemerintah Daerah Kabupaten Sidenreng Rappang. Retrieved from: http://sidrapkab.go.id/site/index.php?/Profil/deta il_profil/21

Souza-Junior, V. D., Mendes, I. A. C., Mazzo, A., \& Godoy, S. (2016). Application of telenursing in nursing practice: an integrative literature review. Applied nursing research, 29, 254-260.

Sunarti, N., \& Patimah, I. (2019). Hubungan Tingkat Pengetahuan Dengan Upaya Pengendalian Tekanan Darah Pada Penderita Hipertensi Di Wilayah Kerja Puskesmas Karangmulya Kecamatan Karangpawitan Kabupaten Garut. Journal of Midwifery and Nursing, 1(3, Aug), 7-11. 
Malahayati International Journal of Nursing and Health Science, Volume 03, No.2, September 2020: 103-109

Telenursing and self-management among patient with hypertension

Trisnowati, H. (2018). Pemberdayaan Masyarakat untuk Pencegahan Faktor Risiko Penyakit Tidak Menular (Studi pada Pedesaan di Yogyakarta). Hasanuddin University.

Warganegara, E., \& Nur, N. N. (2016). Faktor risiko perilaku penyakit tidak menular. Jurnal Majority, 5(2), 88-94.
Wootton, R. Patil N. g., Scoot R., E., \& Ho Kendall.(2015). E-Book: Telehealth in the Developing World.

Sri Sakinah*, Sulkifli Nurdin. STIKES Muhammadiyah Sidrap. *Corresponding author. Email: ns.srisakinah@gmail.com 